\title{
Knowledge Transfer from TNCs and Upgrading of Domestic Firms: The Polish Automotive Sector
}

\author{
GENTILE-LÜDECKE SIMONA \\ University of Bremen, Germany
}

and

\author{
GIROUD AXÈLE* \\ University of Manchester, $U K$
}

\begin{abstract}
Summary. - This paper focuses on the impact of vertical knowledge transfer from foreign affiliates of Transnational Corporations (TNCs) to indigenous Polish suppliers. Firm-level data was collected through a survey among foreign affiliates and domestic suppliers in the Polish automotive sector. The study finds that foreign firms contribute to the knowledge base of local firms, and that the knowledge domestic suppliers receive enables them to enhance their performance, but also that it is R\&D intensity that is critical for suppliers' new knowledge creation. Inter-firm relationships are shown to play a significant role in the process of knowledge transfer and acquisition between foreign firms and domestic suppliers

(c) 2011 Elsevier Ltd. All rights reserved.
\end{abstract}

Key words - TNCs, international knowledge transfer, domestic suppliers, automotive industry, Eastern Europe, Poland

\section{INTRODUCTION}

This paper investigates how downstream foreign transnational corporations (TNCs) contribute through knowledge transfer to the upgrading of their upstream suppliers in the transition economy of Poland. This study focuses on the Polish automotive industry, specifically because this sector has attracted a considerable amount of FDI, and the role of foreign firms is expected to have an influence on the development of the local supply industry. In addition, within the context of Eastern Europe, more analysis on the process of inter-firm knowledge flow, and absorption by local firms, is needed (Jindra, Giroud, \& Scott-Kennel, 2009).

The debate on whether domestic firms benefit or learn from TNCs has attracted considerable attention during recent years in both the development, and international business, literature. In development studies, scholars have long recognized that the key to beneficial effects from FDI depends on whether or not foreign investors reach out to local industry through the establishment of linkages (Kim \& Nelson, 2000), helping domestic firms improve their practices by supplying global buyers (Kelegama \& Foley, 1999), extending their geographical scope, and allowing greater access to export markets (Stiglitz, 1996). In the international business literature, the focus has been on productivity spillovers, notably on the extent to which the presence of FDI affects the firm level productivity of host country firms (Blalock \& Gertler, 2008), as foreign firms bring advanced technology, knowledge, and skills that would spillover to local individuals, firms, and industries (Teece, 1977).

While vertical linkages may have positive effects on domestic firms, they are by no means the automatic result of an influx of foreign TNCs (Görg, Hanley, \& Strobl, 2009). There are, in fact, limitations to linkage-based development (Hansen, Pedersen, \& Petersen, 2009), including the limited upgrading opportunities available for developing country's linkages part- ners in global value chains, and the danger of a lock-in in low value added functions (Humphrey \& Schmitz, 2001). In the automotive industry, for instance, studies have shown that the technology imperative of global supply chains, and the industry's reliance on standardized parts and processes, impede upgrading in local firms, which tend to reside in the lower tiers of the industry (Giuliani \& Bell, 2005). In Central and Eastern Europe, Pavlìnek and Zenka (2011,2) find that although overall automotive production has increased since the early 1990s, the extent to which this development has affected the overall position of domestic automotive manufacturers in the European automotive value-chain is less clear.

The growing body of research on TNCs in emerging markets suggests local suppliers may not all benefit equally from FDI. Differences in firms' capabilities (Blalock \& Simon, 2010), technological competencies (Günther, Jindra, \& Stephan, 2009), and the relationships and ties of domestic firms to the different types of firms in the value chain (McDermott \& Corredoira, 2010) can improve the likelihood of a supplier's ability to upgrade its products and processes. Overall, the significance of the assistance provided by foreign affiliates for the development of competences of local suppliers has been relatively under-studied (Ivarsson \& Alvstam, 2005), with little evidence of the mechanisms that allow linkages to advance upgrading (McDermott \& Corredoira, 2010). The role of TNCs' vertical linkages on firm development can best be captured by researching both foreign affiliates and local firms in dyadic relationships (Meyer, 2004; Giroud \& ScottKennel, 2009), as the use of a local supplier's perspective is

\footnotetext{
* The authors wish to thank Professor Hafiz Mirza for his early involvement with this research. Drafts of this paper were presented at conferences at the Universities of Bocconi in Italy and Nagoya in Japan. The authors also wish to thank the three anonymous reviewers for their insightful comments. Final revision accepted: August 12, 2011.
} 
needed to "explicitly analyze how backward linkages generate a long-term deepening of supplier capabilities to independently improve, and adapt external technology" (Ivarsson \& Alvstam, 2009, 59).

One must differentiate between gains occurring in the short term, improving a firm's performance and capabilities, and those occurring in the long-term, leading to an upgrading of process and product (Giuliani, Pietrobelli, \& Rabellotti, 2005, 552). Suppliers, for instance, respond differently to the introduction of new quality-standards and performancerequirements, related to manufacturing or management systems (Giroud, 2007). In the case of Poland, the relationships between local and foreign firms are still new and in a phase of development (Gentile-Lüdecke \& Giroud, 2009, 287). In the Eastern European automotive supply chains, TNCs hold a dominant position in technology development and transfer to local firms, and Lorentzen, Møllgard, and Rojec (2003) suggest that studies must concentrate on the influences of competences of individual firms, and how technological learning translates into the upgrading of competences over time. This study aims to address these research gaps, and it focuses on the individual interactions between foreign affiliates and local firms, including data from both types of firms to examine the relationship between knowledge transfer and the upgrading of domestic suppliers.

Based on these outlined gaps, there are three main objectives in this paper. Firstly, by looking at both foreign affiliates and domestic suppliers, the paper investigates the process of knowledge transfer/acquisition considering and comparing the views of both foreign affiliates and local suppliers. Secondly, focusing on domestic suppliers, the paper assesses whether they improve their capabilities and competitiveness as a result of their business interaction with foreign TNCs. Finally, the paper seeks to discover whether knowledge acquisition from foreign affiliates results in new knowledge creation by local suppliers. The last stage is critical because the ability to create knowledge is a major source of competitive advantage for firms (Spender, 1996) and what matters most in the long term is what local firms learn and how they are able to develop their own capabilities (Ivarsson \& Alvstam, 2005, 1326).

The reminder of this paper is organized as follows: the next session presents an overview of the Polish automotive sector. Section 3 reviews the previous literature, and presents the conceptual framework deriving working propositions. Section 4 provides a discussion of the empirical results and Section 5 concludes the paper.

\section{POLISH AUTOMOTIVE SECTOR}

This study focuses on the automotive industry in Poland for numerous reasons. Firstly, the automotive industry is often viewed as a leading case for new forms of knowledge and technology diffusion from TNCs to smaller suppliers (Sturgeon \& Florida, 2004), because of its prominence in the FDI in emerging markets, the use of tiered, vertical production networks, and the incorporation of both modular systems and lean production. Inter-firm interaction and intensive knowledge sharing are particularly important to supply chains in the automotive sector (Domański \& Gwosdz, 2009). Secondly, the liberalization of FDI policy in Poland has led to an increase in investment projects in the automotive sector. Poland has relied heavily on policies that promote market incentives, and the entry of TNCs to drive the reorganization and renewal of its automotive industry. In Central and Eastern Europe,
Tier 1 suppliers are typically dominated by a small number of foreign TNCs, while domestic suppliers tend to be numerous in Tier 2 and Tier $3^{1}$, the upgrading prospects of lower Tier suppliers is a critical issue. Indeed, the highly concentrated structure of the automotive industry may create little room for an independent process and product ${ }^{2}$ upgrade for these small suppliers (Gereffi, Humphrey, \& Sturgeon, 2005; Giuliani et al., 2005). The historical pattern of development in the automobile industry in Poland has been analyzed previously (Pavlínek, Domański, \& Guzik, 2009), and in general terms, it can be treated as an evolutionary process of adaptation to major shocks that have occurred both endogenously and exogenously to the industry.

The automotive industry in Poland dates back to the $1920 \mathrm{~s}$, when the Italian vehicle manufacturer Fiat founded Polski Fiat with the intention of establishing an assembling plant. The Great Depression and the Second World War scuttled those plans. Fiat renewed its license in 1948 but actual production of designated vehicles did not begin until 1967, in the Fabryka Samochodow Osobowyh (FSO) facility.

In the period between the collapse of Communism and the recent accession to the EU, the country underwent dramatic changes in its economic and political systems, with the privatization of state-owned facilities, significant foreign investments in the production of vehicles and parts, a phased liberalization of a previously protected sector, and the adoption of EU trade and competition rules. Poland has adopted favorable FDI policies in the automotive industry, which has resulted in enhanced FDI, and the component sector has gained particular importance in the last decade (Pavlínek et al., 2009). Large manufacturers, including Daewoo, General Motors, and Volkswagen, have begun operations, and have attracted a number of their subcontractors to Poland. Just like other transition economies, Poland had to compensate for systemic defects inherited from the past (Dries \& Swimmen, 2004), and TNCs have played a significant role in economic activities (Günther et al., 2009). In the automotive sector, TNCs took charge of the reorganization of the industry by diffusing the concept of lean production throughout the value chain and giving incentives to suppliers to improve quality and reduce costs by introducing practices such as JIT and TQM.

Nowadays, the local automotive supply industry has grown substantially, and contributes significantly, to the Polish economy. Automotive suppliers account for as much as $81 \%$ of the total employment within the motor vehicle industry. Between 2002 and 2007, their exports grew by more than $27 \%$ and, in 2007 , more than half of the exports from the automotive sector were accounted for by parts and components. Local manufacturing concentrates largely on key, and complex systems, and not merely on basic subcomponents and accessories. Between 1996 and 2006, the share of high value-added exports increased from $4 \%$ to $33.3 \%$. This reflects a considerable enhancement of local manufacturing capabilities, and, in this context, the issue of locally owned firms' upgrading is critical. Some significant challenges, however, remain. The reliance on the existence of, and support from, foreign companies is not a guarantee of prosperity in the long term - and capability enhancement also depends upon the learning activity of local suppliers themselves. The increases in wages in recent years and the shortage of qualified personnel are becoming serious limitations to further growth. In this context, the ability of the local component industry to continuously upgrade its technological competencies and create new knowledge is linked to the industry's ability to join the global supplier network of the automotive industry. 
The next section explores the theoretical considerations behind the relationship between TNCs, knowledge transfer, and local suppliers' capabilities.

\section{CONCEPTUAL FRAMEWORK}

The debate over the impact of TNCs on host country development is extensive (see Meyer, 2004 for a review), and different streams of literature bring complementary insights into factors facilitating knowledge transfer, acquisition, and the use of externally acquired knowledge by local suppliers. The international business literature emphasizes that TNCs possess superior knowledge in foreign markets (Caves, 1996), in part because they operate complex knowledge systems, with inflow and outflow of knowledge internally and externally (Foss \& Dos Santos, 2011). Development studies contributions on TNCs' linkages (Hirschman, 1958), focus on voluntary and involuntary knowledge transfer (Narula \& Zanfei, 2005, chap. 12 ), which lead to an improvement in supplier performance and competencies (Lorentzen et al., 2003). The channels through which foreign affiliates impact upon their domestic suppliers includes increased demand for intermediate products, or requirements for product quality and timely delivery. Those may act as an incentive for the suppliers to enhance their capabilities (Blomström \& Kokko, 2001), or the foreign affiliate may engage in knowledge transfer to support upgrading among suppliers (Giroud, 2003; Jordaan, 2011). Knowledge transfer can take place through the direct sharing of process and product, technology, manufacturing techniques, and management know-how. The transfer can be carried out through on-going interaction between partners, through supplier programs (Giroud, 2003; Ivarsson \& Alvstam, 2005), or through the training of employees (Blomström \& Kokko, 2001; Okada, 2004).

Studies considering the impact of TNCs of host country firms adopt three orientations. On one hand, some scholars have begun to shift attention toward the "demand-side" (local firms) effect of spillover, investigating the role of absorptive capacity (Blalock \& Gertler, 2009), that is the capacity to acquire, assimilate, transform, and apply externally sourced knowledge (Zahra \& George, 2002). Other studies, meanwhile, have examined inter-firm relationships advocating that some forms of relationships may offer more valuable knowledge than others (McDermott \& Corredoira, 2010), and that it is not simply the quantity of ties, but the quality of interfirm relationships that may be beneficial for upgrading (Giroud \& Scott-Kennel, 2009; Saliola \& Zanfei, 2009). Finally, other scholars look at the "supply-side" factor, recognizing the role of heterogeneity in TNCs and their strategies. Firm heterogeneity needs to be integrated into studies on knowledge spillovers and backward linkages to domestic suppliers (Jindra et al., 2009); especially if one considers that the transferability of technology and re-deployable capabilities to local firms vary depending on the role of a subsidiary (Spencer, 2008).

In this paper, these views are combined to integrate the heterogeneity of TNCs (the supply side) and of domestic suppliers (the demand side), and the role of relationships in enhancing the potential for knowledge transfer, acquisition, and absorption. A series of propositions is developed to identify the role of affiliate characteristics, relationship characteristics, and local supplier characteristics in explaining knowledge transfer and acquisition, before considering issues affecting knowledge absorption and the impact of knowledge acquired.

\section{(a) Foreign affiliates' characteristics}

When applied to the case of Japanese firms in Asia, Kiyota, Matsuura, Urata, and Wei (2008) argue that unobserved affiliate-specific characteristics explain a large part of the variation of the backward linkages among foreign affiliates. The literature suggests that there are three types of affiliate characteristics, or heterogeneities that influence knowledge transfer to local suppliers. Firstly, the roles affiliates adopt in supporting the exploitation of existing TNC technological assets in host countries or in creating new assets for the TNC, determine the level of internal and external knowledge exchange (Cantwell \& Mudambi, 2005). Secondly, technological competencies of foreign affiliates (often measured through R\&D intensity) influence their capacity to create new technical knowledge (Marin \& Sasidharan, 2010). This suggests that the greater the extent of knowledge resources in the affiliate network, the greater the opportunity for firms in the network to access knowledge and therefore to innovate through merging their own knowledge with acquired knowledge. For this reason, several studies point to the positive outcome of technological intensity in foreign affiliates and backward linkages creation (Belderbos, Capannelli, \& Fukao, 2001; Lorentzen et al., 2003; Jindra et al., 2009). Thirdly, extant literature on foreign affiliates demonstrates that the greater the extent of affiliate autonomy, the better the ability of the affiliate to form favorable, external network linkages with other companies and institutions in its local environment (Forsgren, Holm, \& Andersson, 2005; Foss \& Dos Santos, 2011), and thus have a positive impact on local vertical business partners (Jindra et al., 2009; Hansen et al., 2009, 125).

It is suggested, therefore, that the above mentioned affiliate characteristics drive the likelihood of the foreign affiliate transferring knowledge to local suppliers:

Proposition 1. Affiliate level characteristics (role, $R \& D$ activity and degree of autonomy) influence the transfer of knowledge to domestic suppliers.

\section{(b) Inter-firm relationships' characteristics}

When looking at the process of inter-organizational knowledge transfer, buyer-supplier relationships increase in prominence (Squire, Cousins, \& Brown, 2009). Evidence from research on TNCs in emerging markets and on the automotive industry suggests that upgrading varies among local-owned suppliers according to the ties a supplier has to different types of firms in the value chain. Multiple, strong social relationships to TNCs allow domestic suppliers to access key information about new products, processes, and international standards (Blalock \& Gertler, 2009; Saliola \& Zanfei, 2009),

Theories that take an evolutionary perspective on technology development stress that long-term relationships are an essential ingredient for close, inter-firm learning between customers and suppliers. Recent studies from Ivarsson and Alvstam $(2005,2009)$ on the heavy truck sector and bus plant of AB Volvo in Brazil, China, India, and Mexico confirm this view. In a case study of technology learning among IKEA suppliers in China and Southeast Asia, Ivarsson and Alvstam (2011) find that repeated interaction facilitates inter-organizational learning, where the tacit element can be developed specifically and gradually. McDermott and Corredoira (2010), looking at the automotive sector in Argentina, suggest that the upgrading of local suppliers depends upon more than the 
quantity of ties; the quality of inter-firm relationships appears to be particularly beneficial for upgrading.

To summarize, it can be posited that both the quality of the relationship and its length have an influence on the likelihood to transfer/acquire knowledge:

Proposition 2. Inter-firm relationships' characteristics influence the transfer of knowledge from foreign affiliates to domestic suppliers as well as the acquisition of knowledge by domestic suppliers from foreign affiliates.

\section{(c) Suppliers' characteristics}

Research has shown that the speed and the success with which local suppliers internalize and translate externally acquired knowledge into their own capability through learning is largely determined by their capacity to absorb the knowledge, and their ability to upgrade it regularly (Ernst \& Kim, 2002). It is the learning effort of indigenous firms that make the inflow of foreign knowledge valuable (Chung \& Lee, 2010), as the payoff of access to external sources of knowledge increases with the absorptive capacity of local suppliers (Zahra \& George, 2002; Stephan, 2005; Saliola \& Zanfei, 2009).

Absorptive capacity is not a one-dimensional concept, and it consists of various firm-level characteristics that can influence local firms' knowledge acquisition (Schmidt, 2008). Such characteristics include R\&D activity (Blalock \& Gertler, 2009), the development of skills and training (Giuliani \& Bell, 2005; Sinani \& Meyer, 2004), the ability to stimulate and organize the transfer of knowledge across departments, functions, and individuals (Daghfous, 2004), and the technological capabilities and level of technical influence (Lorentzen et al., 2003; Petroni \& Panciroli, 2002). All of these constitute the critical resources needed to generate technical change and equip local suppliers with the ability to acquire knowledge and use the knowledge acquired for commercial means. Building on those elements, the following proposition is derived:

Proposition 3. Absorptive capacity of domestic suppliers influences the acquisition of knowledge from foreign affiliates.

\section{(d) Knowledge absorption and impact}

Studies regarding the impact of foreign firms on the capability upgrading of local firms have arisen only recently. While some authors look at the short-term effect of linkages on local firms, focusing on performance improvement, others look at the long-term effect, that is, the improvement of the innovative capability of the local firms. In the case of Malaysia and Vietnam, foreign affiliates' managers estimate that the greatest improvement by local suppliers occurs in terms of quality, cost, and delivery (Giroud, 2007, 169). Other key areas of performance improvement occur in terms of increased investment and improved access to finance (Crone \& Roper, 2001). Developing studies indicate that there is a positive effect of backward linkages on suppliers' performance, and the link between knowledge acquisition and absorption, thus, the following is proposed:

Proposition 4. Knowledge acquired from foreign affiliates leads to an improvement in domestic suppliers' performance.
Focusing on linkages and knowledge transfer from TNCs, Ivarsson and Alvstam (2009, 2011) examine whether local suppliers develop innovative capabilities based on formal R\&D, which are needed to generate product and process upgrading (Giuliani et al., 2005), and to keep pace with the ever expanding technological frontiers. This is particularly relevant for the automotive industry where there is constant pressure on suppliers to cut the costs of their components (Humphrey \& Memedovic, 2003). These recent studies suggest that participating in a value chain offers a direct advantage from the knowledge acquired to upgrade competencies (Saliola \& Zanfei, 2009). It is, therefore, proposed that:

Proposition 5. Knowledge acquired from foreign affiliates influences domestic suppliers' creation of new knowledge.

Research has found that differences in firms' capabilities (Saliola \& Zanfei, 2009; Blalock \& Simon, 2010) enable some firms to benefit more than others from downstream FDI. This explains why upgrading may fluctuate according to the ties created with different firms in the value chain $(\mathrm{McD}$ ermott \& Corredoira, 2010). For this reason, it is suggested that, together with the knowledge acquired from foreign affiliates, firm capabilities (or absorptive capacity) and relational ties also influence local suppliers' performance improvement and new knowledge creation.

Proposition 6. Absorptive capacity and inter-firm relationships' characteristics influence domestic supplier's performance improvement and creation of new knowledge.

The paper's conceptual framework provides a detailed account of the reason why, when studying knowledge transfer from TNCs, the upgrading of domestic suppliers, foreign affiliates' and suppliers' characteristics, and inter-firm relationships, are integrated. In the next section, the methodological steps adopted in this paper are explained.

\section{EMPIRICAL STUDY}

Primary data was collected through a field survey carried out in Poland, between April and August 2006, among the 380 manufacturers of parts and components (141 foreign affiliates and 239 domestic suppliers) included in the automotive database updated yearly by the Polish Chamber of Automotive industry. Additionally, a series of semi-structured interviews were conducted with the managers of 12 foreign affiliates to discuss and clarify the results of the survey.

A questionnaire was sent by mail to all the companies in the sample. Two different questionnaires were constructed, one for foreign affiliates and one for domestic suppliers. This made it possible to include firm-specific factors related to both types of firms involved in knowledge transfer.

Our data is composed of two samples, one for domestic suppliers and one for foreign affiliates. A total of 41 responses were received from the domestic suppliers (a 17\% response rate). 17 companies are operating as Tier 2 suppliers, 16 as Tier 3 suppliers, and 8 companies as Tier 4 suppliers. A total of 23 responses (again a 17\% response rate) were received from foreign affiliates, all operating as Tier 1 companies. Both samples are treated and analyzed separately, but overlapping questions between both versions of the questionnaires allow for the cross-comparison of results. 
Despite the relatively small sample sizes, it can be asserted that both respondent samples are representative. Within the foreign affiliates' sample, the majority of parent companies of respondent firms are located in Western Europe $(80 \%$ of firms); most firms operate under the wholly owned mode of operation; the three largest products manufactured or assembled are engines $(37.5 \%)$, the car body $(25 \%)$, and electric equipment for the automotive industry $(16.7 \%)$. This sample is representative of the overall TNCs' population operating in the Polish automotive sector.

A similar comparison between the overall population and our sample of domestic suppliers indicates that our sample is also representative. In terms of company size and sectors of activity, firms have a representative distribution. For size, $45 \%$ of firms in the sample have fewer than 100 employees, $32.5 \%$ have between 100 and 250 employees, and $22.5 \%$ have more than 250 employees.

Representativeness of the sample is further reinforced by the high number of dyadic relationships identified, since $47 \%$ of the foreign subsidiaries, and $29.2 \%$ of the domestic suppliers, match with companies in the respondent sample.

Given the nature of the research method adopted for data collection, two separate procedures are used to address concerns related to non-response bias. A $t$-test indicates that no significant differences exist $(t=0.991$ for the foreign subsidiaries' sample and $t=0.258$ for the domestic suppliers' sample) between respondent and non-respondent samples in terms of size (measured as number of employees). Following the procedure used in previous research (Oppenheim, 1992), answers provided by late and early respondents are compared for key variables of interest, that is, knowledge transferred for foreign subsidiaries and knowledge acquired, performance improvement and new knowledge creation for domestic suppliers. The assumption here is that late respondents (those that do not respond initially but do so in the follow-up stages of the survey) can be compared to nonrespondents because they may not have responded without repeated encouragements by the researcher. A $t$-test indicates that early and late respondents show no significant differences for key variables of interest, neither for foreign subsidiaries' ( $t=0.869$ for knowledge transfer), nor for the domestic suppliers' sample $(t=0.821$ for knowledge acquired; $t=0.938$ for improvement; $t=0.182$ for new knowledge creation).

Data is analyzed by means of a series of 4 linear regression models, testing relationships between firm-level and relationship-level characteristics, knowledge transfer/acquisition, and impact on suppliers.

\section{(a) Measurement of variables}

A description of the variables' measurement is presented in Table 1. The dependent variables in the empirical analysis include knowledge transferred by foreign affiliates, knowledge acquired by domestic suppliers, performance improvement of domestic suppliers and domestic suppliers' new knowledge creation. Knowledge transferred and Knowledge acquired refer to technical and managerial knowledge including: informational support, product-related support, process-related support, and organizational, and managerial, know-how. Based on previous research, Performance improvement measures different elements of the improved capabilities of suppliers: process improvement, product quality improvement, reduction of lead time, increase in sales, improvement in productivity, and decrease in price. New knowledge creation combines three dimensions: the introduction of new products, of new services (product upgrading), and of new technology (process upgrading) as a result of the relationship with foreign affiliates.

Independent variables refer to foreign affiliates' characteristics, local suppliers' characteristics, and relationships' characteristics.

Variables for foreign affiliates' characteristics include Multidomestic and Multiregional (see Table 1), Autonomy, and $R \& D$ affiliate.

To measure inter-firm relationships, two variables are developed, Relationship affiliate and Relationship supplier. Each variable combines an assessment of the relationships in terms of trust, shared vision, communication, information sharing, and commitment among the parties.

In the case of the domestic suppliers, an additional measure is introduced, to consider the need of firms in transition economies to move from the mindset of short-term advantage, adversarial, buyer-supplier relationships (Whitley, Henderson, Czaban, \& Lengyel, 1996), inherited from the past, to longterm, cooperative, buyer-supplier relationships. Short term contract and Long term contract measure the duration of the contractual relationship between domestic suppliers and foreign affiliates looking at, respectively, short term and long term relationships.

The measure of local suppliers' characteristics combines several dimensions of absorptive capacity previously identified in the literature. These include Technological penetration and Technical influence. Knowledge exchange measures suppliers' activities to stimulate knowledge exchange within their firm. Training refers to the training activities carried out by suppliers while $R \& D$ supplier refers to their level of R\&D intensity.

Several control variables are used within the models, namely Age affiliate and Age supplier (they represent the number of years of operation), Size affiliate and Size supplier (these measure the number of employees) and Tier supplier (a dummy variable showing whether the supplier falls within the Tier 2, Tier 3 or Tier 4 category).

\section{(b) Empirical analysis}

Descriptive results (see Table 2) show that the type of knowledge most frequently transferred/acquired is "organizational and managerial know-how" and "product technology support". Both foreign affiliates' and local suppliers' responses indicate that the knowledge that is most frequently transferred/acquired resides in the "assistance in implementing quality assurance system", "product design" and "technical specifications".

Domestic suppliers, regardless of the Tier level they belong to, assessed whether they were able to improve their capabilities as a result of knowledge acquisition from foreign affiliates. The most significant improvement resides in the fields of "quality of production" and "increase in sales'. With regard to the impact of knowledge acquisition on the suppliers' capacity of creating new knowledge, the results indicate that 27 domestic suppliers were able to create new knowledge as a result of their business interaction with foreign affiliates (most notably in terms of "replacement of older machinery", "investment in new equipment", "widening of the product range", and "introduction of new process technology such as CNC machinery"). In the case of Tier 3 and Tier 4 suppliers, knowledge creation is almost exclusively related to product innovation, whereas Tier 2 suppliers knowledge creation spans across both product and process innovation.

In order to identify the factors explaining knowledge transfer/acquisition and the impact of knowledge acquisition on local suppliers, a series of regression analyses are con- 
Table 1. List of variables

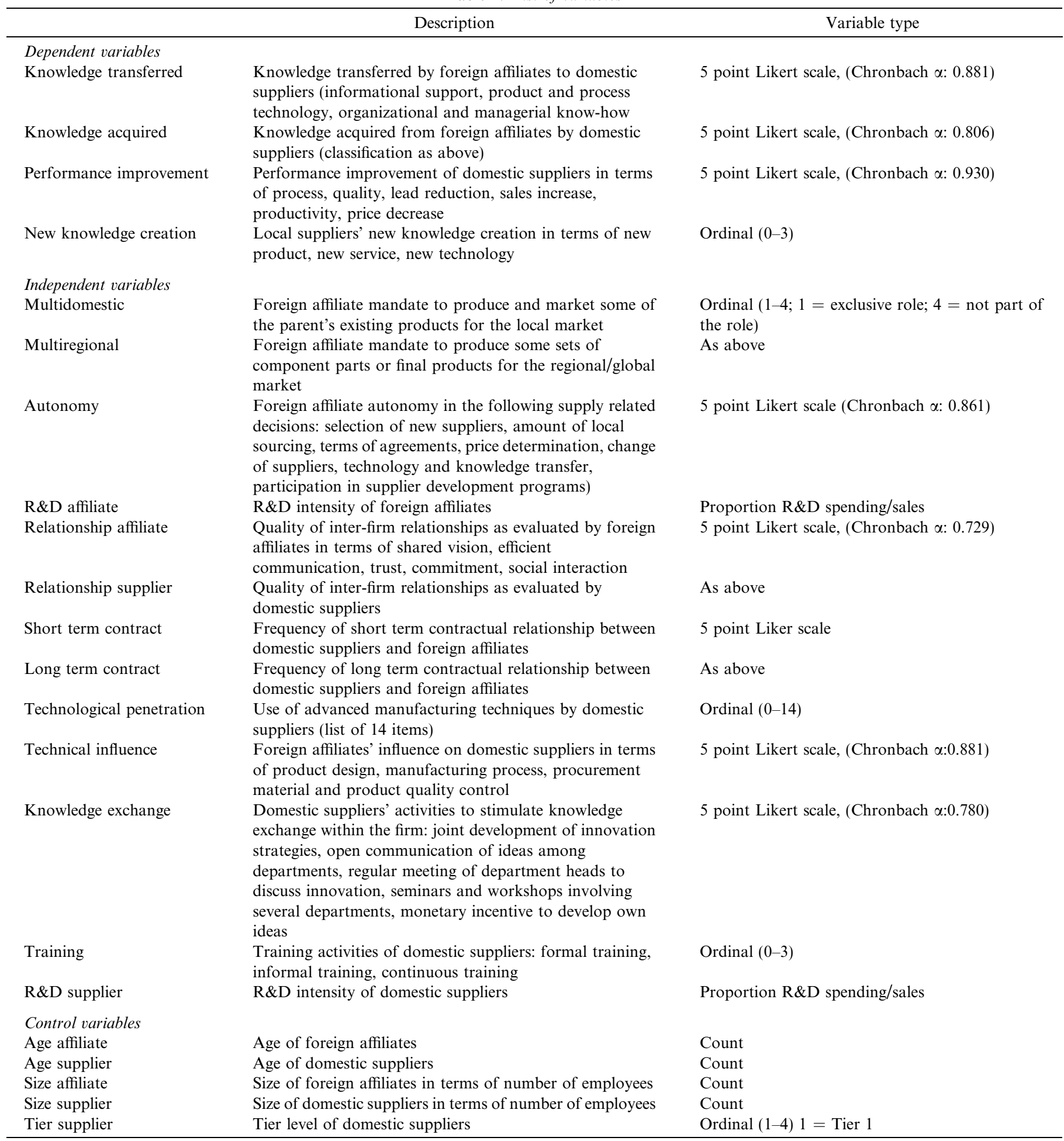

ducted. Model 1 focuses on foreign affiliates and factors explaining knowledge transfer to domestic suppliers. Model 2 focuses on suppliers and factors explaining knowledge acquisition from foreign affiliates. Models 3 and 4 concentrate on factors explaining domestic suppliers' performance improvement and new knowledge creation. A preliminary correlation analysis among variables did not signal any problem of multicollinearity between constructs; this was confirmed by the variance inflation factor (VIF), for which all values stand below 2.9. Results of the regression analyses are reported in Tables 3 and 4 . Results suggest that several explanatory factors influence knowledge transfer/acquisition, performance improvement, and knowledge creation by local suppliers. 
Table 2. Knowledge transferredlacquired

\begin{tabular}{|c|c|c|c|c|}
\hline \multirow[t]{2}{*}{ Knowledge type } & \multicolumn{2}{|c|}{ Affiliates $(n=23)$} & \multicolumn{2}{|c|}{ Suppliers $(n=41)$} \\
\hline & Mean $^{\mathrm{a}}$ & SD & Mean & SD \\
\hline \multicolumn{5}{|l|}{ Product technology } \\
\hline Product know-how & 3.43 & 1.037 & 3.33 & 1.328 \\
\hline Product design & 2.65 & 1.027 & 2.49 & 1.267 \\
\hline Technical consultation & 3.09 & .996 & 3.00 & 1.132 \\
\hline R\&D cooperation & 3.73 & .985 & 3.70 & 1.043 \\
\hline \multicolumn{5}{|l|}{ Process technology } \\
\hline Machinery $^{*}$ & 3.48 & .898 & 4.00 & 1.177 \\
\hline Technical support ${ }^{* * *}$ & 2.87 & .968 & 4.15 & 1.040 \\
\hline Visits $^{* * *}$ & 2.70 & .926 & 4.25 & .954 \\
\hline Cooperation club & 3.82 & .733 & - & - \\
\hline \multicolumn{5}{|c|}{ Organizational and managerial know-how } \\
\hline Inventory $^{* * *}$ & 3.13 & 1.014 & 4.03 & 1.310 \\
\hline Quality system & 2.43 & .896 & 2.37 & 1.090 \\
\hline New practice ${ }^{* * *}$ & 3.74 & .752 & 4.41 & .880 \\
\hline \multicolumn{5}{|l|}{ Informational support } \\
\hline Information exchange & 3.22 & .795 & 3.43 & 1.083 \\
\hline Purchase order & 3.67 & .730 & 3.64 & 1.387 \\
\hline Market information & 3.62 & .669 & 3.64 & 1.038 \\
\hline Business association & 3.95 & .605 & - & - \\
\hline
\end{tabular}

${ }^{\mathrm{a}}$ Mean $=1$ : very frequently-5: never

${ }^{*}$ Significant difference between samples under 2-tailed $t$-test $(p<0.10)$. ${ }^{* * *}$ Significant difference between samples under 2- tailed $t$-test $(p<0.05)$.

${ }^{* * *}$ Significant difference between samples under 2- tailed $t$-test $(p<0.01)$.

Table 3. Results of regression analysis on knowledge transferred. Foreign affiliate sample $(n=23)$

\begin{tabular}{lc}
\hline Variables & Model 1 \\
\hline Dependent variable & Knowledge transferred \\
Control variables & $.292^{*}$ \\
Age affiliate & .061 \\
Size affiliate & \\
Affiliate characteristics & -.157 \\
Multidomestic & $.221^{*}$ \\
Multiregional & $.388^{* *}$ \\
Autonomy & $-.282^{*}$ \\
R\&D affiliate & \\
Relationships characteristics & $.337^{* *}$ \\
Relationship affiliate & .780 \\
$R^{2}$ & .677 \\
Adjusted $R^{2}$ & $7.587^{* * *}$ \\
$F$ & \\
\hline${ }^{*} p<0.10$. & \\
${ }^{* *} p<0.05$. & \\
${ }^{* * *} p<0.01$. &
\end{tabular}

\section{(c) Factors explaining knowledge transferlacquisition}

(i) Foreign affiliates' characteristics

Model 1 focuses on answers provided by foreign affiliates. Results indicate that Multiregional, Autonomy, and $R \& D$ affiliate, influence knowledge transfer to domestic suppliers, as suggested in Proposition 1, but not always as expected. Autonomy in supply-related decisions is the most important factor influencing knowledge transfer to domestic suppliers. This confirms and complements other recent studies on backward linkages, some of them looking at transitional economies
(Jindra et al., 2009). The Multiregional mandate also has a positive, significant influence on knowledge transfer. This shows that foreign TNCs that produce in Poland for the regional market (Europe, Eastern Europe) are more likely to transfer knowledge to domestic suppliers than affiliates oriented toward the local market.

$R \& D$ affiliate is negatively related to knowledge transfer to domestic suppliers. As R\&D tends to be higher in those firms involved in competence-creating functions, and which have gained a higher degree of strategic independence, one could argue that those foreign affiliates are likely to demand welldeveloped supply capabilities (Hansen et al., 2009), and utilize technology-intensive proprietary components, often produced in developed countries, or by highly performing foreign owned suppliers operating in Poland. This is not, however, what our results show. Instead, our results are similar to those of Nicolini and Resmini (2006), who find that, in the context of Eastern Central Europe, high tech firms are better able to generate positive externalities on domestic firms in less developed countries like Bulgaria than in countries such as Poland, because the technological gap between foreign and domestic firms is narrower.

Age affiliate is positively related to knowledge transfer. It can be argued that age is a good predictor of acquaintance with the host environment. As such, the longer the affiliate has been in operation, the more embedded it is with local business partners, reflecting the notion of "vintage effects", as described by Kiyota et al. (2008) in a recent study on local procurement in South-East Asia. In this case, foreign affiliates have established a base of indigenous suppliers, with an enhanced knowledge transfer to those suppliers.

\section{(ii) Inter-firm relationships' characteristics}

Relationship affiliate and Relationship supplier are found to influence knowledge transfer/acquisition significantly in both Models 1 (providing foreign affiliates' responses) and 2 
Table 4. Results of regression analysis on knowledge acquired, domestic suppliers' performance improvement and new knowledge creation $(n=39)$

\begin{tabular}{|c|c|c|c|c|c|}
\hline Variables & Model 2 & Model 3a & Model 3b & Model 4a & Model 4b \\
\hline Dependent variables & $\begin{array}{l}\text { Knowledge } \\
\text { acquired }\end{array}$ & $\begin{array}{l}\text { Performance } \\
\text { improvement }\end{array}$ & $\begin{array}{l}\text { Performance } \\
\text { improvement }\end{array}$ & $\begin{array}{l}\text { New knowledge } \\
\text { creation }\end{array}$ & $\begin{array}{c}\text { New knowledge } \\
\text { creation }\end{array}$ \\
\hline $\begin{array}{l}\text { Absorptive capacity } \\
\text { Technological penetration } \\
\text { Technical influence } \\
\text { Training } \\
\text { Knowledge exchange } \\
\text { R\&D supplier }\end{array}$ & $\begin{array}{c}.050 \\
.057 \\
-.362^{* *} \\
-.155 \\
.038\end{array}$ & $\begin{array}{c}.0 .35 \\
-.019 \\
.040 \\
.747^{* * *} \\
-.140\end{array}$ & $\begin{array}{l}-.143 \\
.192 \\
-.003 \\
.344^{*} \\
.199\end{array}$ & $\begin{array}{l}-.139 \\
-.210 \\
-.006 \\
.104 \\
.291^{* *}\end{array}$ & $\begin{array}{c}-.119 \\
.011 \\
-.085 \\
-.453^{* *} \\
.351^{* *}\end{array}$ \\
\hline
\end{tabular}

${ }^{*} p<0.10$.

${ }^{* *} p<0.05$.

${ }^{* * *} p<0.01$.

(providing local suppliers' responses). Model 1 shows that there is a positive relationship between Relationship affiliate and Knowledge transferred by the foreign affiliate to its domestic suppliers. This confirms that the stronger the ties between the foreign affiliate and its domestic suppliers (especially in terms of commitment and trust), the more likely the foreign affiliate is to transfer knowledge to local firms. The importance of inter-firm relationships is confirmed by domestic suppliers, and in Model 2, both variables Relationship supplier and Long term contract positively influence Knowledge acquired.

The establishment of long-term relationships is particularly relevant for indigenous suppliers in transition economies. In this environment, the state played a significant role in firms' strategies, making it even more difficult for firms to face continuing levels of market uncertainty and change during the transition process. Adversarial and opportunistic relationships initially prevailed in local firms as managers tended to compete for political support and short-term advantages (Whitley et al., 1996). Long-term relations are key to knowledge exchange among partners and in the case of transition economies, the benefit has been, and still continues to be, access to foreign technology and knowledge. From a local supplier's perspective, long-term relationships matter because a supplier is unlikely to make major investments in dedicated assets to suit a customer's requirements in the absence of longterm contractual agreements.

Overall, strong support for Proposition 2 is found, meaning that inter-firm relationship characteristics have a strong influence on knowledge transferred from foreign affiliate, and knowledge acquired by domestic suppliers.

\section{(iii) Suppliers' characteristics}

Results of Model 2 show that absorptive capacity does not have an influence on Knowledge acquired. Only one of the measures of absorptive capacity, Training, has a significant influence on Knowledge acquired, but, unexpectedly, with a negative sign. Thus, Proposition 3 is not supported.

This result contrasts with the findings of Minbaeva, Pedersen, Björkman, Fey, and Park (2003). The findings of the latter suggest that employee training, within the recipient organization, plays a vital role in the recipient's employee capability building, and the degree of knowledge transfer. There exist several kinds of on-the-job training, and the type, and the adequacy, of the training provided are important factors to consider. Results from the interviews with managers of foreign affiliates suggest that the environment also matters. Training often takes place on the foreign affiliate's site, and it is frequently delivered by Headquarters' personnel, with little or no knowledge of the Polish language and market. As a result, the effectiveness of such training can be minimum.

In Model 2 it is interesting to note the negative significance of two control variables Size supplier and Age supplier. Arguably this may be justified with the characteristics of Poland as transition economy. Firm size has a number of implications for the importance of external knowledge. On one side, external knowledge offers potential for small firms whose internal knowledge base may be small; on the other, gathering external knowledge requires the commitment of resources which small firms may not be able to spare. In this case, the issue that size has a negative effect on the acquisition of knowledge could mean that, possibly, economies of scale are negated by organizational inefficiencies in large Polish firms. During the interviews, some foreign affiliates' managers suggested that large companies have the potential to produce large quantities, but that they lack specialization. This can be one of the reasons why they are more difficult to manage and develop.

Looking at the negative relationship between Age supplier and Knowledge acquired it could be argued that the youngest 
companies, which have been mostly operating in a market economy system, may have a higher capacity to take in new knowledge, while older firms, due to their longer years of activity in a planned economy context, may be less used to taking in new knowledge, even if they may benefit from an experience advantage. The explanation given by foreign affiliates' managers during the interviews is that, for many big companies, which have been operating for many years, a difficulty remains in understanding that the business conditions of Poland are likely to be the same in the future; and that the investment required when they do acquire knowledge, does not involve high risk.

\section{(c) Factors explaining knowledge absorption and impact for local suppliers}

Models $3 \mathrm{a}$ and $3 \mathrm{~b}$, and $4 \mathrm{a}$ and $4 \mathrm{~b}$, explore the factors explaining when domestic suppliers are more likely to derive long-term beneficial impacts as a result of knowledge acquisition from a foreign affiliate, and their interaction with those customers. Partial support for Proposition 6 is found in Models $3 \mathrm{a}$ and $4 \mathrm{a}$, which assess the influence of relationship characteristics and absorptive capacity on domestic suppliers' Performance improvement and New knowledge creation. The role of knowledge acquired from foreign affiliates is subsequently assessed in Models $3 \mathrm{~b}$ and $4 \mathrm{~b}$.

Models $3 \mathrm{a}$ and $4 \mathrm{a}$ show that there is a positive, significant relationship between Relationship supplier and both Performance improvement and New knowledge creation indicating that relationships help firms to adapt, innovate and learn (McEvily \& Marcus, 2005). Inter-organizational closeness promotes a common understanding between foreign affiliates and domestic suppliers which can be expected to facilitate mutual learning, and the creation of new knowledge. Chang and Gotcher (2008) confirm this view in a recent study investigating the interaction between relationship learning and dyadic knowledge creation in 118 Taiwanese supplier-international buyer relationships. In terms of absorptive capacity Model 3a shows that Knowledge exchange, is significantly related to Performance improvement. Knowledge exchange relates to the ability of an organization as a whole to stimulate and organize the transfer of knowledge across departments, functions, and individuals. As such, this demonstrates that for knowledge acquisition to result in enhanced improvement, the supplier needs to possess sufficient internal organization, transformation, and the internalization processes required for the dissemination and assimilation of such knowledge.

Model 4 a considers factors explaining New knowledge creation. The $R \& D$ intensity of suppliers is positively and significantly related to New knowledge creation. This demonstrates that high technological capability facilitates the development, and learning potential of vertical linkages for local firms (Liu, Wang, \& Wei, 2009). The significant, negative relationship between Supplier Tier and New knowledge creation confirms findings by Humphrey and Memedovic (2003) on the automotive industry in emerging markets. Although market pressures and the introduction of international standards forces suppliers, initially, to make improvement in terms of products and processes, the use of modularization (i.e., producing only standardized components) limits access for the lower tier suppliers to new information, knowledge, and activities of assemblers and top tier suppliers. In comparison, lower tier suppliers have limited internal resources, and are less able to upgrade. Arguably, modularization is not always linked to a static vision of knowledge exchange; in fact, interactive relationships between assembler and suppliers facilitate knowl- edge exchange (McDermott \& Corredoira, 2010). This may explain results in Model 4b, when the variable Knowledge acquired is added, as the relationship between Supplier tier and New knowledge creation becomes insignificant while the positive influence of Relationship supplier remains significant.

In Models $3 \mathrm{~b}$ and 4b, the role of Knowledge acquired in explaining domestic suppliers' Performance improvement and New knowledge creation is assessed. Strong support for Proposition 4 is found in Model 3b, as Knowledge acquired is significantly, and positively, related to Performance improvement.

Results do not support Proposition 5 in Model 4b, Knowledge acquired from foreign affiliates is not significantly related to New knowledge creation. This may be explained by the different nature of new knowledge that can be created. Results of a recent study on the upgrading of the automotive industry in Central and Eastern European countries (Pavlínek \& Ženka, 2011) confirm the different dynamic of upgrading. The study, based on the Czech automotive industry, recognizes that automotive suppliers are under constant pressure from higher-tier suppliers to lower the production costs, while achieving high product quality. Consequently, while process upgrading is a necessary precondition for all automotive suppliers to sustain competitiveness, the relentless price pressure from customers leaves few resources to finance the development of a unique product and technologies that could improve the position of the supplier in the value chain. Product upgrading may be taking place more selectively, and predominantly among higher tiers suppliers (Pavlínek \& Ženka, 2011, 581). The measurements adopted in this paper for Performance improvement and New knowledge creation do not allow to differentiate between process and product upgrading, however, qualitative interviews suggest that foreign affiliates are, indeed, more focused on providing knowledge that is likely to lead to process upgrading. Managers acknowledge that their objective is to transfer knowledge needed to fulfill contracts to their suppliers, and encourage the latter to adhere to rigid quality standards. The support provided by foreign affiliates toward suppliers' production processes may not necessarily provide them with independent capabilities needed to develop new products.

\section{CONCLUSIONS}

This paper contributes to the growing debate on the way TNCs facilitate firm-level upgrading in transition economies, through the establishment of linkages and the transfer of knowledge to domestic suppliers. Using a sample of TNCs (Tier 1) and domestic suppliers (Tier 2, Tier 3 and Tier 4), the types of firm-level and relational factors that facilitate knowledge transfer/acquisition are analyzed. The paper provides evidence on the impact knowledge acquisition from foreign affiliates has on local firms' capabilities, and the degree of innovativeness.

The empirical analysis highlights four important results. First, it suggests that foreign affiliates with a high degree of autonomy in supply-related decisions and with a multiregional mandate are more likely to engage in knowledge transfer to domestic suppliers. Second, knowledge acquired from foreign affiliates is likely to improve the performance of domestic suppliers. Third, strong relational ties support collaboration and a mutual understanding, which, in turn, help firms learn faster. Finally, knowledge acquired from foreign affiliates is not significantly related to supplier's innovativeness. To create new knowledge, domestic suppliers rely on their own R\&D capability, and the upgrading effort is not led by the buyer (Giuliani \& Bell, 2005). 
Overall, the results support the evolutionary perspective on technology development (Kim \& Nelson, 2000) suggesting that technology transfer from industrialized to developing economies is based on local inter-firm linkages, with a relationship between incremental firm development arising from external sources of knowledge, and the firms' own evolving capabilities.

Similarly, our results confirm and add to those of previous studies on local firms upgrading in the automotive sector. Although some studies suggest that upgrading possibilities of small domestic suppliers could be very limited (Barnes \& Kaplinsky, 2000; Humphrey \& Memedovic, 2003), others, focusing on Central and Eastern European countries, demonstrate that domestic suppliers can, and do, improve competencies after interaction with TNCs. This paper confirms findings that demonstrate that upgrading possibilities for local suppliers exist, especially in terms of process and product upgrading (Domański \& Gwosdz, 2009; Pavlìnek et al., 2009).

The results in this paper have notable managerial implications for foreign affiliates and domestic firms, all the more important since Poland strongly promotes FDI in the automotive sector. The first of these implications is that foreign firms may consider the adoption of supplier development programs. Indeed, relationships that promote disciplined, regular discussions, with customers, about new product and processes, appear most beneficial for suppliers (McDermott \& Corredoira, 2010). Domestic suppliers may consider the means to maximize the effects of their interaction with foreign firms. Knowing that buyer-supplier relationships are closely related to performance improvement, Polish companies should consider ways to cultivate and maintain strong long-term relationships based on trust and mutual satisfaction. The future development of domestic suppliers will depend, above all, on their ability to absorb new knowledge. While locally owned companies in the automotive sector have already achieved a good level of quality standard, independent domestic research should be developed, as it will enhance levels of absorptive capacity.

Given our results, how should policy makers in Poland maximize the benefits of TNCs investment in their local economy? The issue is critical. FDI has played a pivotal role in the transformation of the post-communist economies of Central and Eastern Europe for more than a decade but the wage increases of recent years, and the shortage of qualified personnel may undermine the low-cost production advantages of Poland. If this happens, the ability to offer advantages other than cost advantages would be crucial to help Poland sustain its competitiveness. Also of importance to policymakers is the fact that not all foreign investors benefit local firms equally through linkages and spillovers. Our findings support the view that FDI policies should be differentiated, based on the principle that different policy instruments apply to different TNC strategies.
The Polish government could maximize the benefits to be gained from foreign firms' operation in the automotive industry by supporting the external technological environment in which locally owned firms operate. This will allow a greater development of local channels of knowledge transmission (Manolopoulos, Papanastassiou, \& Pearce, 2005), which is fundamental to the development of Poland's competitive advantage. Ties to universities appear strongly and positively associated with product upgrading (McDermott \& Corredoira, 2010).

Policies providing support for domestic firms to strengthen their absorptive capacity should be pursued. Human capital investment, for instance, could constitute an effective longterm policy for taking advantage of foreign capital and for favouring linkage creation and knowledge transfer. To support the development of human capital, governments can consider providing direct subsidies to firms investing in knowledge as well as country-wide policies (Bell \& Pavitt, 1993, 201-2), aiming at favouring intra-firm training in the activities of design, production engineering, quality control, and R\&D. These measures can facilitate cooperation between foreign investors and domestic firms in R\&D. An additional instrument to help indigenous companies respond to the challenges of foreign firms could also be a government-sponsored National Supplier Development Programme (NSDP). This could provide funding and technical assistance for small and medium-sized enterprises that supply large companies.

To conclude, the results of this study allow suggestions for future research. At the methodological level, more longitudinal applications need to be investigated, in a structured way, allowing for the better understanding of the dynamics of knowledge acquisition, knowledge absorption, and new knowledge creation. Secondly, in-depth case studies of domestic suppliers could generate a deeper understanding of the process of knowledge absorption and creation, and the relationship with foreign affiliates. In particular, future studies should distinguish between product and process upgrading, as these differ by groups of sectors (Giuliani et al., 2005) and with unequal rates and depths within and across firms (Schmitz, 2004). The inability to differentiate between the two types of upgrading is a shortcoming of this study. Additionally, a deeper focus on the relationships between local suppliers and foreign affiliates could help in understanding whether learning and ability to coordinate is facilitated when firms develop routines and "pragmatic mechanisms" that promote joint problem solving (Helper, McDuffie, \& Sabel, 2000).

Future research is also needed to explore knowledge transfer and the impact, in different stages, of supply relationships. This study did not differentiate stages within the supply relationship, yet, evidence is found that the relationship quality differs depending upon the level of understanding between partners (see for instance the work of Duanmu \& Fai, 2007), which is likely to change with time.

\section{NOTES}

1. Tier 1 suppliers supply pre-assembled autonomous subsystems of components or modules (such as cockpit units, drive units, roofs, door or seats) as well as the most technically complex parts to the car assembler; Tier 2 suppliers assemble smaller and less complex components from smaller parts. Their components are often only a part of a particular module (such as the production of condensers for air-conditioning, tyres, dashboard components, lights and engine components). Depending on the product, these components are either supplied to Tier 1 suppliers or directly to the car assembler. Tier 3 suppliers produce simple components with low value-added in production such as rubber gaskets, hoses, insulation, simple plastic parts, seat cloth, fastening, screws, simple castings. These simple components are then used for the assembly of more complex auto parts. Tier 4 suppliers supply raw materials such as steel and glass work (Pavlínek and Janák, 2007, 139-140). 
2. Process upgrading refers to the transformation of inputs into outputs more efficiently by reorganizing the production system or introducing superior technology. Product upgrading relates to moving into more sophisticated product lines in terms of increased unit values. Product and process upgrading tend to develop at unequal rates and depths within and across firms (Schmitz, 2004) and to depend upon interfirm linkages and the governance of value chains (Giuliani et al., 2005).

\section{REFERENCES}

Barnes, J., \& Kaplinsky, R. (2000). Globalization and the death of the local firms: The automobile components sector in South Africa. Regional Studies, 34(9), 797-812.

Belderbos, R., Capannelli, G., \& Fukao, K. (2001). Backward vertical linkages of foreign manufacturing affiliates: Evidence from Japanese multinationals. World Development, 29(1), 189-208.

Bell, M., \& Pavitt, K. (1993). Technological accumulation and industrial growth: Contrasts between developed and developing countries. Industrial and Corporate Change, 2(2), 157-210.

Blalock, G., \& Gertler, P. J. (2008). Welfare gains from foreign direct investment through technology transfer to local suppliers. Journal of International Economics, 74(2), 402-421.

Blalock, G., \& Gertler, P. J. (2009). How firm capabilities affect who benefits from foreign technology. Journal of Development Economics, 90(2), 192-199.

Blalock, G., \& Simon, D. H. (2010). Do all firm benefit equally from downstream FDI? The moderating effect of local supplier's capabilities on productivity gains. Journal of International Business Studies, 40, 1095-1112.

Blomström, M., \& Kokko, A. (2001). Foreign direct investment and spillovers of technology. International Journal of Technology Management, 22(5/6), 435-454.

Cantwell, J., \& Mudambi, R. (2005). MNE competence-creating subsidiary mandates. Strategic Management Journal, 26(12), $1109-1128$

Caves, R. E. (1996). Multinational enterprise and economic analysis (2nd ed.). Cambridge: Cambridge University Press.

Chang, K.-H., \& Gotcher, D. (2008). Relationship learning and dyadic knowledge creation in international subcontracting relationships: The supplier's perspective. International Journal of Technology Management, 41(1/2), 55-74.

Chung, M. Y., \& Lee, K. (2010). How is absorptive capacity formed in Korea? From foreign technology acquisition to indigenous $R \& D$ Paper presented at the Globelics 2010, 8th International Conference Kuala Lumpur.

Crone, M., \& Roper, S. (2001). Local learning from multinational plants: Knowledge transfer in the supply chain. Regional Studies, 35(6), $535-548$.

Daghfous, A. (2004). Absorptive capacity and the implementation of knowledge-intensive best practices. SAM Advanced Management Journal, 69(2), 21-27.

Domański, B., \& Gwosdz, K. (2009). Toward a more embedded production system? Automotive supply networks and localized capabilities in Poland. Growth and Change, 40(3), 452-482.

Dries, L., \& Swimmen, J. F. (2004). Foreign direct investment, vertical integration, and local suppliers: Evidence from the Polish dairy sector. World Development, 32(9), 1525-1544.

Duanmu, J. L., \& Fai, F. (2007). A processual analysis of knowledge transfer: From foreign MNEs to Chinese suppliers. International Business Review, 16(4), 449-473.

Ernst, D., \& Kim, L. (2002). Global production network, knowledge diffusion, and local capability formation. Research Policy, 31(8/9), $1417-1429$.

Forsgren, M., Holm, U., \& Andersson, U. (2005). Managing the embedded multinational. A business network view. Cheltenham, UK; Northampton, USA: Edward Elgar.

Foss, N. J., \& Dos Santos, J. F. P. (2011). A knowledge system approach to the multinational company: Conceptual grounding and implications for research. In Asmussen, C.G., Pedersen, T., Devinney, T. M., Tihanyi, L. (Eds). Dynamics of Globalization: Location-Specific Advantages or Liabilities of Foreignness? (Vol. 24, pp. 425-454) Advances in International Management.

Gentile-Lüdecke, S., \& Giroud, A. (2009). Does the East learn from the West? How polish automotive suppliers learn from western MNEs. Journal of East-West Business, 15(3), 271-294.
Gereffi, G., Humphrey, J., \& Sturgeon, T. (2005). The governance of global value chains. Review of International Political Economy, 12(1), 78-104.

Giroud, A. (2003). Transnational corporations, technology, and economic development: Backward linkages and knowledge transfer in South East Asia. Cheltenham and Northampton: Edward Elgar.

Giroud, A. (2007). MNEs vertical linkages: The experience of Vietnam after Malaysia. International Business Review, 16(2), 159-176.

Giroud, A., \& Scott-Kennel, J. (2009). Multinationals' linkages in international business: A framework for analysis. International Business Review, 18(6), 555-566.

Giuliani, E., \& Bell, M. (2005). The micro-determinants of meso level learning and innovation: Evidence from a Chilean wine cluster. Research Policy, 34(1), 47-68.

Giuliani, E., Pietrobelli, C., \& Rabellotti, R. (2005). Upgrading in global value chains: Lessons from Latin American clusters. World Development, 33(4), 549-573.

Görg, H., Hanley, A., \& Strobl, E. (2009). Creating backward linkages from multinationals: Is there a role for financial incentives? Review of International Economics, 19(2), 245-259.

Günther, J., Jindra, B., \& Stephan, J. (2009). Does local technology matter for foreign investors in Central and Eastern Europe?-Evidence from the IWH FDI Micro Database. Journal of East West Business, 15(3-4), 210-247.

Hansen, M. W., Pedersen, T., \& Petersen, B. (2009). MNC strategies and linkage effects in developing countries. Journal of World Business, 44(2), 121-130

Helper, S., McDuffie, J. P., \& Sabel, C. (2000). Pragmatic collaborations: Advancing knowledge while controlling opportunism. Industrial and Corporate Change, 9(3), 443-488.

Hirschman, A. O. (1958). The strategy of economic development. New Haven: Yale University Press.

Humphrey, J., \& Memedovic, O. (2003). The global automotive industry value chain: What prospects for upgrading by developing countries. Vienna: UNIDO.

Humphrey, J., \& Schmitz, H. (2001). Governance in global value chain IDS Bulletin, 32, 19-29.

Ivarsson, I., \& Alvstam, C. G. (2005). Technology transfer from TNCs to local suppliers in developing countries: A study of AB Volvo's truck and bus plants in Brazil, China, India and Mexico. World Development, 33(8), 1325-1344.

Ivarsson, I., \& Alvstam, C. G. (2009). Learning from foreign TNCs: A study of technology upgrading by local suppliers to AB Volvo in Asia and Latin America. International Journal of Technology Management, 48(1), 56-76.

Ivarsson, I., \& Alvstam, C. G. (2011). Upgrading in global value chains: A case study of technology-learning among IKEA-suppliers in China and Southeast Asia. Journal of Economic Geography, 11(4), 731-752.

Jindra, B., Giroud, A., \& Scott-Kennel, J. (2009). Subsidiary roles, vertical linkages and economic development. Journal of World Business, 44(2), $167-179$.

Jordaan, J. A. (2011). FDI, local sourcing, and supportive linkages with domestic suppliers: The case of Monterrey, Mexico. World Development, 39(4), 620-632.

Kelegama, S., \& Foley, F. (1999). Impediments to promoting backward linkages from the garment industry in Sri Lanka. World Development, 27(8), 1445-1460.

Kim, L., \& Nelson, R. (2000). Technology, learning, and innovation: Experiences of newly industrializing economies. Cambridge, UK: Cambridge University Press.

Kiyota, K., Matsuura, T., Urata, S., \& Wei, Y. (2008). Reconsidering the backward linkages of foreign affiliates: Evidence from Japanese Multinationals. World Development, 36(8), 1398-1414.

Liu, X., Wang, C., \& Wei, Y. (2009). Do local manufacturing firms benefit from transactional linkages with multinational enterprises in China? Journal of International Business Studies, 40(7), 1113-11130. 
Lorentzen, J., Møllgard, P., \& Rojec, M. (2003). Host country absorption of technology: Evidence from automotive supply networks in Eastern Europe. Industry and Innovation, 10(4), 415-432.

Manolopoulos, D., Papanastassiou, M., \& Pearce, R. D. (2005). Technology sourcing in multinational enterprises and the roles of subsidiaries: An empirical investigation. International Business Review, 14, 249-267.

Marin, A., \& Sasidharan, S. (2010). Heterogeneous MNC subsidiaries and technological spillovers: Explaining positive and negative effects in India. Research Policy, 39(9), 1227-1241.

McDermott, G. A., \& Corredoira, R. (2010). Network composition, collaborative ties, and upgrading in emerging-market firms: Lessons from the Argentine autoparts sector. Journal of International Business Studies, 41(2), 308-329.

McEvily, B., \& Marcus, A. (2005). Embedded ties and the acquisition of competitive capabilities. Strategic Management Journal, 26(11), $1033-1055$

Meyer, K. (2004). Perspectives on multinational enterprises in emerging economies. Journal of International Business Studies, 35(4), 259-276.

Minbaeva, D., Pedersen, T., Björkman, I., Fey, C. F., \& Park, H. J. (2003). MNC knowledge transfer, subsidiary absorptive capacity, and HRM. Journal of International Business Studies, 34(6), 586-599.

Narula, R., \& Zanfei, A. (2005). Globalisation and innovation: The role of multinational enterprises. In J. Fagerberg, D. Mowery, \& R. Nelson (Eds.), The oxford handbook of innovation. Oxford: Oxford University Press.

Nicolini, M., \& Resmini, L. (2006). The impact of MNEs on domestic firms in CECCs: A micro-econometric approach. Milan: Bocconi University.

Okada, A. (2004). Skills development and interfirm learning linkages under globalization: Lessons from the Indian automobile industry. World Development, 32(7), 1265-1288.

Oppenheim, A. (1992). Questionnaire Design, Interviewing and Attitude Measurement. London Pinter

Pavlínek, P., \& Janák, L. (2007). Regional restructuring of the Skoda Auto supplier network in Czech Republic. European Urban and Regional Studies, 14(2), 133-155.

Pavlínek, P., Domański, B., \& Guzik, R. (2009). Industrial upgrading thorough foreign direct investment in Central European automotive manufacturing. European Urban and Regional Studies, 16(1), 43-63.

Pavlínek, P., \& Ženka, J. (2011). Upgrading in the automotive industry: Firm-level evidence from Central Europe. Journal of Economic Geography, 11(3), 559-586.
Petroni, A., \& Panciroli, B. (2002). Innovation as a determinant of suppliers' roles and performances: An empirical study in the food machinery industry. European Journal of Purchasing \& Supply Management, 8(3), 135-149.

Saliola, F., \& Zanfei, A. (2009). Multinational firms, global value chains and the organization of knowledge transfer. Research Policy, 38, 369-381.

Schmidt, T. (2008). Absorptive capacity-One size fits all? A firm-level analysis of absorptive capacity for different kinds of knowledge. Managerial and Decision Economics, 31(1), 1-18.

Schmitz, H. (2004). Local enterprises in the global economy: issues of governance and upgrading. Northampton, MA: Edward Elgar.

Sinani, E., \& Meyer, K. (2004). Spillovers of technology transfer from FDI: The case of Estonia. Journal of Comparative Economics, 32(3), $1-22$.

Spencer, J. W. (2008). The impact of multinational enterprise strategy on indigenous enterprises: Horizontal spillovers and crowding out in developing countries. Academy of Management Review, 33(2), 341-361.

Spender, J. C. (1996). Making knowledge the basis of a dynamic theory of the firm. Strategic Management Journal, 17(Winter Special Issue), $45-62$.

Squire, B., Cousins, P. D., \& Brown, S. (2009). Cooperation and knowledge transfer within buyer-supplier relationships: The moderating properties of trust, relationship duration and supplier performance. British Journal of Management, 20(4), 461-477.

Stephan, J. (2005). Technology transfer via foreign direct investment in Central and Eastern Europe: Theory-Methods of research-Empirical evidence. Houndsmill, Basingstoke: Palgrave Macmillan.

Stiglitz, J. E. (1996). Some lessons from the East Asian miracle. The World Bank Research Observer, 11, 151-177.

Sturgeon, T., \& Florida, R. (2004). Globalization, deverticalization, and employment in the motor vehicle industry. In M. Kenney, \& R. Florida (Eds.), Locating global advantage: Industry dynamics in the international economy. Stanford, CA: Stanford University Press.

Teece, D. J. (1977). Technology transfer by multinational firms: The resource cost of transferring technological know-how. The Economic Journal, 87(June), 242-261.

Whitley, R., Henderson, J., Czaban, L., \& Lengyel, G. (1996). Trust and contractual relations in an emerging capitalist economy: The changing trading relationships of ten large Hungarian enterprises. Organization Studies, 17(3), 397-429.

Zahra, S. A., \& George, G. (2002). Absorptive capacity: A review, reconceptualization and extension. Academy of Management Review, 27(2), 185-203.

\section{SciVerse ScienceDirect}

